\title{
ELEMENTS AND INDICATORS OF INCLUSIVE ECONOMIC DEVELOPMENT
}

\author{
Alina Zhukovska \\ West Ukrainian National University, Ternopil, Ukraine \\ https://orcid.org/0000-0003-0891-1952
}

\section{Oleksandr Dluhopolskyi}

West Ukrainian National University, Ternopil, Ukraine

https://orcid.org/0000-0002-2040-8762

CMESTE

JEL Category: I14, I38, J11, J21, 015, 038, 043, 044

\begin{abstract}
The concept of inclusive economic development and the basic concepts that underlie it are examined in the scientific paper. The definitions of "inclusive growth" offered by the leading international organizations and scientists are studied. The methods of inclusive economic development assessment are analyzed: the methodology of the Asian Development Bank, the method of calculating of inclusive development index offered by the World Economic Forum in Davos (Switzerland) likewise the method of inclusive rural development assessment is substantiated. Their main advantages and disadvantages are revealed. The policy of inclusive growth should be based on institutional support and good governance policy. To determine the level of inclusive economic development the key components should be considered: political, economic, social, and environmental. The need to improve the existing methods by including the environmental component and indicators that determine the degree of equal opportunities for the citizens regardless of their age, gender, physical abilities, religion, nationality, and place of residence is shown.
\end{abstract}

Keywords: inclusive development, inclusive growth, inclusive development concept, inclusive development index

\section{INTRODUCTION}

The thesis of the insufficiency of economic development to ensure the full effective economic growth was firstly voiced during the 2014 UN report «Ensuring Sustainable Human Progress: Reducing Vulnerability and Building

Address of the corresponding author: Oleksandr Dluhopolskyi 莑"dlugopolsky77@gmail.com
Sustainability», which states that 2.2 billion people live in poverty (Human Development Report, 2014). Under the World Bank estimates, $12 \%$ of the world's population lives in poverty; almost 1 billion people live on less than $\$ 1.25$ a day (World Bank President Outlines Strategy, 2015); more than a billion people in the world do not have access to the clean water, 1.6 billion - to electricity and 5.4 - to the Internet; 2.5 billion people do not have accounts in the financial institutions. Thus, with the dominant model of economic development, which is practiced by most countries 
of the world, the economic and social inequality grows, the absolute poverty deepens, and the significant part of the population does not improve welfare. The famous American economist $T$. Piketty warns that such deepening inequalities pose a threat not only to innovation but also to the market democracy, public confidence, and the free market system of capitalism (Piketty, 2014).

That is why in 2017 at the 48th World Economic Forum in Davos (Switzerland) it was proposed to change the priorities of the economic policy, which should be reoriented on more effective counteraction to insecurity and inequality that accompanies the technological change and globalization. It is the sustainable allencompassing progress, accompanied by an increase of the people's incomes together with the simultaneous increase of the economic opportunities, security, and quality of life that should be recognized as the main goal of economic development, rather than GDP growth as it was previously considered. The analysis of the main macroeconomic indicators of the country may show the achievement of a high level of economic development, but a significant part of the population will not be "included" in the process of GDP and, consequently, in the distribution of public goods. Poverty becomes one of the topical issues (Zhukovska, 2019; Koziuk, et al., 2021; Koziuk, et al., 2020).

\section{LITERATURE REVIEW}

The concept of inclusive economic development is a new approach to ensure the effective functioning of the state, which emerged in the XXI century. The main provisions of this concept were developed in 2008 by the members of the Commission for Growth and Development under the leadership of the Nobel Laureate M. Spence and published in the work "The Growth Report. Strategies for Sustained Growth and Inclusive Development» (The Growth Report, 2008). This concept was further developed in 2009 in the paper (lanchovichina, Lundstrom, 2009), in which the authors studied the conceptual foundations of inclusive growth and identified the constraints that can influence sustainable and inclusive growth on the example of the Zambian economy.
Today, both international organizations and individual scholars are working on the issues of ensuring inclusive economic growth. Table 1 provides some definitions of «inclusive growth» proposed by the leading international organizations.

Table 1. Definitions of «inclusive growth» offered by the leading international organizations

\begin{tabular}{|c|c|}
\hline $\begin{array}{l}\text { International } \\
\text { organization }\end{array}$ & Definition \\
\hline World Bank & $\begin{array}{l}\text { Inclusive growth is rapid } \\
\text { sustainable growth, spread to all } \\
\text { sectors of the economy, which } \\
\text { attracts a significant part of the } \\
\text { country's labor resources and is } \\
\text { characterized by equal } \\
\text { opportunities in access to the labor } \\
\text { market and resources }\end{array}$ \\
\hline $\begin{array}{l}\text { Organization } \\
\text { for Economic } \\
\text { Co-operation } \\
\quad \text { and } \\
\text { Development } \\
\text { (OECD) }\end{array}$ & $\begin{array}{l}\text { Inclusive growth is stable and } \\
\text { comprehensive growth in terms of } \\
\text { employment opportunities, which } \\
\text { needs support from public } \\
\text { institutions to solve problems in the } \\
\text { labor market }\end{array}$ \\
\hline $\begin{array}{l}\text { European } \\
\text { Commission }\end{array}$ & $\begin{array}{l}\text { Inclusive growth is the provision of } \\
\text { high levels of employment, } \\
\text { investment in education, the fight } \\
\text { against poverty and the } \\
\text { modernization of labor markets, } \\
\text { social protection systems, and the } \\
\text { promotion of greater social } \\
\text { cohesion. }\end{array}$ \\
\hline $\begin{array}{l}\text { International } \\
\text { Monetary } \\
\text { Fund (IMF) }\end{array}$ & $\begin{array}{l}\text { Inclusive growth is an increase in } \\
\text { growth by providing a single space } \\
\text { for investment and productive } \\
\text { employment }\end{array}$ \\
\hline $\begin{array}{l}\text { United Nations } \\
\text { Development } \\
\text { Program }\end{array}$ & $\begin{array}{l}\text { Inclusive development is a } \\
\text { development that complements } \\
\text { human development and includes } \\
\text { a wide range of changes - from } \\
\text { environmental sustainability (ie } \\
\text { climate change, environmental } \\
\text { pollution, energy scarcity) and } \\
\text { natural disasters to the } \\
\text { development of rural communities, } \\
\text { citizens' incomes, health care } \\
\text { costs, education, and recreation. }\end{array}$ \\
\hline
\end{tabular}

Along with the international organizations, some scientists are working on the issues of ensuring inclusive economic growth. Table 2 lists several definitions of "inclusive growth" proposed by the leading researchers. 
Table 2. Definitions of «inclusive growth» proposed by the leading researchers

\begin{tabular}{|c|c|}
\hline Researchers & Definition \\
\hline $\begin{array}{l}\text { Ifzal Ali, Hyun } \\
\text { Hwa Son (2007) }\end{array}$ & $\begin{array}{l}\text { Inclusive growth is growth that } \\
\text { expands the social opportunities } \\
\text { and depends on two factors: the } \\
\text { average opportunities available to } \\
\text { the population and the way they } \\
\text { are distributed (Ali, Son, 2007). }\end{array}$ \\
\hline $\begin{array}{l}\text { Cielito F. Habito } \\
(2009)\end{array}$ & $\begin{array}{l}\text { Inclusive growth is the growth of } \\
\text { gross domestic product (GDP), } \\
\text { which leads to a significant } \\
\text { reduction in poverty (Habito, } \\
\text { 2009). }\end{array}$ \\
\hline $\begin{array}{l}\text { Ianchovichina } \\
\text { Elena, } \\
\text { Lundstrom } \\
\text { Susanna } \\
\text { (2009) }\end{array}$ & $\begin{array}{l}\text { Inclusive growth is an increase in } \\
\text { the growth of the economy, as well } \\
\text { as equalization of conditions for } \\
\text { investment and productivity } \\
\text { growth in the employment } \\
\text { opportunities (lanchovichina, } \\
\text { Lundstrom, 2009). }\end{array}$ \\
\hline $\begin{array}{c}\text { Ganesh } \\
\text { Rauniyarand, } \\
\text { Ravi Kanbur } \\
(2010)\end{array}$ & $\begin{array}{l}\text { Inclusive growth is growth that is } \\
\text { accompanied by a reduction in } \\
\text { income inequality so that benefits } \\
\text { are accrued disproportionately } \\
\text { and primarily to those with lower } \\
\text { incomes (Rauniyarand, Kanbur, } \\
\text { 2010). }\end{array}$ \\
\hline $\begin{array}{l}\text { Terry McKinley } \\
\qquad(2010)\end{array}$ & $\begin{array}{l}\text { Inclusive growth is the } \\
\text { achievement of sustainable } \\
\text { growth that creates and expands } \\
\text { the economic opportunities and } \\
\text { provides greater access to them to } \\
\text { all members of society in the form } \\
\text { of participation in the growth and } \\
\text { benefit from it (McKinley, 2010). }\end{array}$ \\
\hline $\begin{array}{c}\text { Stephan Klasen } \\
(2010)\end{array}$ & $\begin{array}{l}\text { Inclusive growth is growth that } \\
\text { benefits all sections of society, } \\
\text { including the poor, the middle- } \\
\text { income, and even the rich (Klasen, } \\
2010 \text { ). }\end{array}$ \\
\hline $\begin{array}{c}\text { Joyeeta Gupta, } \\
\text { Courtney } \\
\text { Vegelin } \\
(2016)\end{array}$ & $\begin{array}{l}\text { Inclusive growth is growth that not } \\
\text { only creates new economic } \\
\text { opportunities but also provides } \\
\text { equal access to opportunities } \\
\text { created for all segments of society, } \\
\text { especially the poor (Gupta, } \\
\text { Vegelin, 2016) }\end{array}$ \\
\hline $\begin{array}{c}\text { Zsolt Darvas, } \\
\text { Guntram Wolf } \\
\qquad(2016)\end{array}$ & $\begin{array}{l}\text { Inclusive growth is growth that } \\
\text { goes beyond the one-dimensional } \\
\text { growth of gross domestic product } \\
\text { (GDP) and includes employment } \\
\text { opportunities, access to } \\
\text { education, health care, care for the } \\
\text { environment, active participation } \\
\text { in the economy and society } \\
\text { (Darvas, Wolf, 2016). }\end{array}$ \\
\hline
\end{tabular}

Even though the study of the concept of "inclusive growth" is widely represented in the scientific literature, the problem of its measurement, definition of its components, and indicators have not been examined enough.

\section{PROBLEM STATEMENT}

The first attempt to measure inclusive economic growth is the concept of inclusive growth, developed by the staff of the Asian Development Bank (ADB) and documented in detail by I. Ali and J. Zhuang in 2007 and 2010 under the 2020 Strategy (Ali, Zhuang, 2007). It is suggested to measure inclusive growth under the following strategies:

1. economic growth and employment opportunities. Rapid, efficient, sustainable economic growth and employment opportunities expand economic opportunities for all members of society, absorb surplus labor in highly skilled jobs, create resources for governments to improve access to education and health services, infrastructure, and social protection systems.

2. social inclusion and ensuring equal access to economic opportunities. Social inclusion implies that all segments of the population, including those in difficult life circumstances, have equal opportunities. Ensuring access to education, medicine, and infrastructure for all citizens without exception is a key component of an inclusive growth strategy.

3. a system of social protection, which is designed to support the poor and help citizens in difficult life circumstances. The special role of the social protection system is to meet the needs of the poor and those who, due to circumstances beyond their control, are unable to take advantage of available opportunities.

The policy of inclusive growth is offered to be based on the institutional support and good governance that promotes inclusive growth, in which all members of society can benefit and promote growth (fig. 1).

The system of inclusive growth indicators developed by the staff of the Asian Development Bank (ADB) includes 35 indicators that characterize: 1) poverty and inequality (income and lack of income); 2) economic growth and 
employment; 3) accessibility to key infrastructure facilities; 4) access to education and health care; 5) access to infrastructure and utilities; 6) equality and opportunities regardless of gender; 7) social protection system; 8) proper public administration.

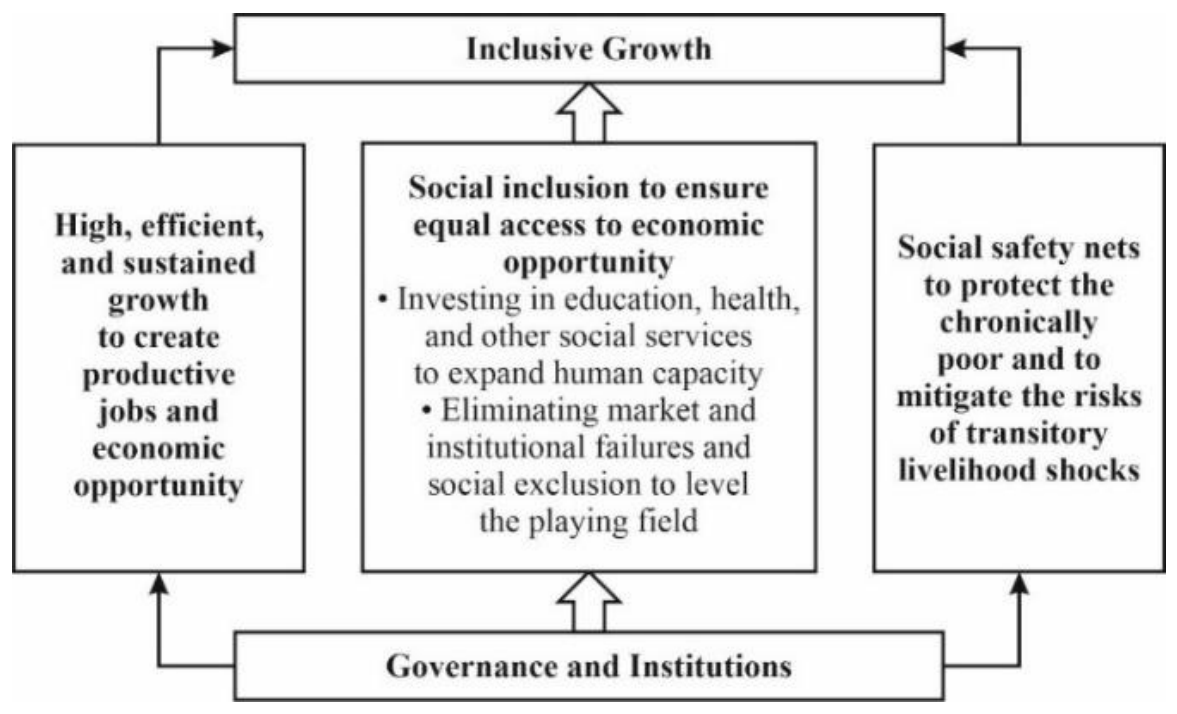

Fig. 1 Policy pillar of inclusive growth

Source: (Ali, Zhuang, 2007)

The presented approach to measuring inclusive growth, although quite thorough, is somewhat limited. Thus, the sixth group of measurement indicators includes indicators that characterize the degree of equal opportunities for citizens regardless of their gender. But you can limit opportunities not only by gender, but also by age, physical ability, religion, nationality, place of residence, and so on. Also, the mentioned system of indicators does not consider the environmental component, which is extremely important for ensuring inclusive economic development and the formation of an inclusive society.

The next attempt to measure the inclusive growth was made at the World Economic Forum in Davos (Switzerland), where the Inclusive Development Index (IDI) (The Inclusive Development Index, 2018), developed by four economists: R. Semans, M. Hanus, G. Corrigan, and M. Berk was presented. The authors developed this index as an alternative to the gross domestic product (GDP) - the main economic indicator that determines the country's position in the world. According to the developers, even though GDP correlates well with the level of employment, it "is not able to reflect the expansion of the digital and globalized economy. In an environment where there is a great variety of goods and services when a significant number of companies operate abroad, it is difficult to correctly determine the amount of the value-added. The growth of the sharing economy increases the number of types of economic activity that are not subject to accounting" (The Inclusive Growth and Development Report, 2017). The authors also emphasize that it is important to consider how GDP is distributed among this population, whether it has a middle class, how freedom of speech is developed, what is the level of education, what is the education system, life expectancy, what is the health care system, dynamics of the country's development and so on. It should be noted that the developers of the inclusive development index do not level the value of GDP but use it as one of the indicators that determine the index of inclusive development of the country.

In addition to GDP estimating, this index measures 11 additional parameters. IDI consists of 12 indicators, which are divided into 3 major groups: 1) growth and development (GDP per capita in US dollars, productivity, healthy life expectancy, employment); 2) inclusiveness (income inequality, poverty level, wealth inequality, median dollar income per day (at purchasing power parity) per capita); 3) equality between generations and sustainability (net savings, $\mathrm{CO} 2$ emissions per unit of GDP, public debt, the ratio of the working-age to the working-age population). First, group indices are calculated, and the final is calculated as the arithmetic mean. Thus, an indicator that 
shows not only the level of production in the country but also the prospects and quality of life is calculated. IIR clearly illustrates how deceptive

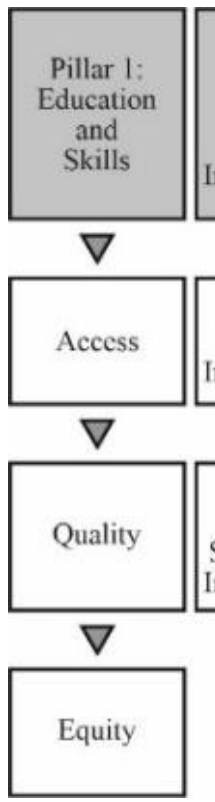

Fig. 2 The concept of inclusive growth and development

Source: (The Inclusive Development Index, 2018)

This system of measuring inclusive economic growth, like the previous one, does not consider the environmental component and the fact that discrimination and disability can occur not only based on gender and age but also based on religion, nationality, place of residence, and physical capabilities.

Ukrainian researchers also have some experience in inclusive growth estimating. Thus, S.V. Kyryziuk success can be, measured only by the production capacity (Fig. 2). in (Kyryziuk, 2020), developed the consolidated indicators of sectoral and component inclusion, which allow the assessment of integrated indicators of inclusive rural development (fig. 3).

The advantage of this system of indicators is that it includes three types of inclusion - political, economic, and social. However, the ecological component was passed over the researcher's attention.

\begin{tabular}{|c|c|c|c|c|c|c|}
\hline \multirow{5}{*}{ 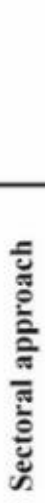 } & & \multicolumn{3}{|c|}{ Types of inequality } & & \\
\hline & & $\begin{array}{l}\text { Access } \\
\text { to goods }\end{array}$ & $\begin{array}{c}\text { Quality } \\
\text { of goods }\end{array}$ & $\begin{array}{c}\text { Divide } \\
\text { of goods }\end{array}$ & & \\
\hline & Political & Indicators & Indicators & Indicators & $\begin{array}{l}\text { Political } \\
\text { inclusion }\end{array}$ & \multirow{3}{*}{ 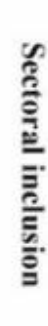 } \\
\hline & Social & Indicators & Indicators & Indicators & $\begin{array}{c}\text { Social } \\
\text { inclusion }\end{array}$ & \\
\hline & Economic & Indicators & Indicators & Indicators & $\begin{array}{l}\text { Economic } \\
\text { inclusion }\end{array}$ & \\
\hline & & $\begin{array}{c}\text { Total access } \\
\text { to goods }\end{array}$ & $\begin{array}{l}\text { Total quality } \\
\text { of goods }\end{array}$ & $\begin{array}{c}\text { Total divide } \\
\text { of goods }\end{array}$ & & \\
\hline & & \multicolumn{3}{|c|}{ Component inclusion } & & \\
\hline
\end{tabular}

Fig. 3 Conceptual framework for measuring the inclusiveness of the rural development 
Thus, the analysis of the existing methods has shown that none of them provides a comprehensive, unified, and integrated approach to inclusive economic development estimating. To determine the level of inclusive economic development, four main components should be considered: political, economic, social, and environmental. Also, the method of determining the level of inclusive economic development should consider not only the degree of equal opportunities for citizens regardless of their age and gender but also the physical capabilities, religion, nationality, and place of residence.

\section{CONCLUSIONS}

In recent years, the inclusive economy and inclusive sustainable growth have become one of the topical issues in the documents of the leading international organizations, as well as in the research of scientists. World practice has developed several methods for inclusive development estimating, the best of which is the method for calculating the index of inclusive development (IID), suggested in 2017 at the 48th World Economic Forum in Davos (Switzerland). There is a controversial thought among the scientists about the feasibility and prospects of using the Inclusive Development Index (INC) as an alternative to the already existing GDP per capita. In our opinion, if the GDP per capita allows us to assess only the level of economic development of the country, the IIR is a much broader indicator, which allows us to assess not only the economic but also the social level of development of the country. However, to calculate the level of inclusive economic development comprehensively, it is expedient to consider the environmental indicators and indicators that determine the degree of equal opportunities for citizens regardless of their age, gender, physical abilities, religion, nationality, and place of residence.

\section{WORKS CITED}

Ali, I., \& Son, H.H. (2007). Measuring Inclusive Growth. Asian Development Review, Vol.24, №1, pp.1131.

Ali, I., \& Zhuang J. (2007). Inclusive Growth toward a Prosperous Asia: Policy Implications. ERD Working Paper Series, Vol.97. Manila: Asian Development Bank.

Ending Poverty and Sharing Prosperity (2015). Global Monitoring Report. Washington DC: The World Bank. 240 p. Available at: http://www.worldbank.org/en/publication/global-monitoringreport.

Exploring and Strengthening the Intersections between Social Protection, Employment and Inclusive Growth (2013). Issues Paper for G20 DWG on Growth with Resilience. Brasilia DF, Brazil: International Policy Centre for Inclusive Growth. 47 p. Available at: http://www.ipcundp.org/publication/26527.

Gupta, J., \& Vegelin C. (2016). Sustainable development goals and inclusive development. International Environmental Agreements: Politics, Law and Economics, Vol.16, Issue 3, p.433-448. DOI 10.1007/s10784-016-9323-z.

Habito, C.F. (2009). Patterns of Inclusive Growth in Asia: Insights from an Enhanced Growth-Poverty Elasticity Analysis. ADBI Working Paper Series, Vol.145. Tokyo, Asian Development Bank Institute. 55 p.

Human Development Report (2014). Sustaining Human Progress: Reducing Vulnerabilities and Building. Resilience. Available at: http://hdr.undp.org/sites/default/files/hdr14-report-en-1.pdf.

lanchovichina, E., \& Lundstrom, S. (2009). Inclusive Growth Analytics: Framework and Application. Policy Research Working Paper, Vol.4851. Washington, DC, World Bank.

Key Indicators for Asia and the Pacific (2011). Framework of Inclusive Growth Indicators. Mandaluyong City, Philippines: Asian Development Bank. Available at: https://sustainabledevelopment.un.org/content/documents. 
Klasen, S. (2010). Measuring and Monitoring Inclusive Growth: Multiple Definitions, Open Questions, and Some Constructive Proposals. ADB Sustainable Development Working Paper Series, Vol.12. Mandaluyong City, Philippines, Asian Development Bank.

Koziuk, V., Dluhopolskyi, O., \& Voznyi, K. (2021). Environmental taxes and emissions of pollutants in the EU: empirical analysis. MEST Journal, Vol.9(1), pp. 68-74.

Koziuk, V., Hayda, Y., Dluhopolskyi, O., \& Kozlovskyi, S. (2020). Ecological performance: ethnic fragmentation versus governance quality and sustainable development. Problemy Ekorozwoju / Problems of Sustainable Development, Vol.15(1), 53-64.

Koziuk, V., Hayda, Y., Dluhopolskyi, O., Martynyuk, V., \& Klapkiv, Y. (2020). Efficiency of environmental taxation in EU countries: comparative analysis. Naukovyi Visnyk Natsionalnoho Hirnychoho Universytetu, Vol.5, pp. 115-121.

Kyryziuk, S.V. (2020). Methodical approaches and empirical evaluations of inclusive urban development. Economics of AIC, Vol.6, pp.113-121. Available at: https://doi.org/10.32317/22211055.202006113

McKinley, T. (2010). Inclusive Growth Criteria and Indicators: An Inclusive Growth Index for Diagnosis of Country Progress. ADB Sustainable Development Working Paper Series, Vol.14. Mandaluyong City, Philippines, Asian Development Bank.

Piketty, T. (2014). Capital in the Twenty-First Century. Cambridge, MA: The Belknap Press.

Rauniyar, G., \& Kanbur, R. (2010). Inclusive Development: Two Papers on Conceptualization, Application, and the ADB Perspective. Mandaluyong City, Philippines, Asian Development Bank.

The Growth Report. Strategies for Sustained Growth and Inclusive Development (2008). Available at: http://gtmarket.ru/news/state/2008/05/25/1686.

The Inclusive Development Index (2018). Summary and Data Highlights. World Economic Forum. Committed to improving the state of the world. Available at: http://www3.weforum.org/docs/WEF_Forum_IncGrwth_2018.pdf.

The Inclusive Growth and Development Report (2017). World Economic Forum. 135 p.

World Bank President Outlines Strategy to End Poverty, Welcomes New Development Partners (2015). Available at: http://www.worldbank.org/en/news/pressrelease/2015/04/07.

Zhuang, J. (2010). Poverty, Inequality, and Inclusive Growth in Asia: Measurement, Policy Issues, and Country Studies. Manila: Asian Development Bank.

Zsolt D., Guntram B., \& Wolff B. (2016). An anatomy of inclusive growth in Europe. Blueprints, Vol.17266. Available at: https://www.bruegel.org/wp-content/uploads/2016/10/BP-2626_10_16-final-web.pdf.

Zukovska, A. (2019). An inclusive approach to economic development: genesis and key points. Herald of Ternopil National Economic University, Vol.2, pp.7-23

Received for publication: $\quad$ 14.06.2021

Revision received: $\quad 26.06 .2021$

Accepted for publication: $\quad$ 06.07.2021 
How to cite this article?

Style - APA Sixth Edition:

Zhukovska, A., \& Dluhopolskyi, O. (2021, July 15). Elements and indicators of inclusive economic development. (Z. Cekerevac, Ed.) MEST Journal, 9(2), 91-98. doi:10.12709/mest.09.09.02.13

Style - Chicago Sixteenth Edition:

Zhukovska, Alina, and Oleksandr Dluhopolskyi. 2021. "Elements and indicators of inclusive economic development." Edited by Zoran Cekerevac. MEST Journal (MESTE) 9 (2): 91-98. doi:10.12709/mest.09.09.02.13.

Style - GOST Name Sort:

Zhukovska Alina and Dluhopolskyi Oleksandr Elements and indicators of inclusive economic development [Journal] // MEST Journal / ed. Cekerevac Zoran. - Belgrade - Toronto : MESTE, July 15, 2021. - 2 : Vol. 9. - pp. 91-98.

Style - Harvard Anglia:

Zhukovska, A. \& Dluhopolskyi, O., 2021. Elements and indicators of inclusive economic development. MEST Journal, 15 July, 9(2), pp. 91-98.

Style - ISO 690 Numerical Reference:

Elements and indicators of inclusive economic development. Zhukovska, Alina and Dluhopolskyi, Oleksandr. [ed.] Zoran Cekerevac. 2, Belgrade - Toronto : MESTE, July 15, 2021, MEST Journal, Vol. 9, pp. 91-98. 